\title{
Strategi Pemerintah Kelurahan Bone-Bone Dalam Menangani Konflik Antar Kelompok Kecamatan Batupoaro Kota Baubau
}

\author{
Abdul Zakimbo' \\ Universitas Muhammadiyah Buton
}

\begin{abstract}
Abstrak; Konflik antar masyarakat seringkali terulang, perlu adanya peran serta pemerintahan tingkat terendah dalam menangani masalah tersebut. Penelitian ini bertujuan untuk mendeskripsikan Strategi Pemerintah Kelurahan Bone-Bone dalam menangani konflik antar kelompok kecamatan batupoaro Kota Baubau. Penelitian ini menggunakan metode penelitian deskripsi kualitatif, dengan maksud untuk menjelaskan problematik yang terjadi dan strategi penangananya dari sisi birokrasi. Penelitian ini menjelaskan bahwa strategi pemerintah kelurahan dalam menangani konflik warga dilakukan dengan tiga tahapan yaitu: pencegahan konflik melalui pemetaan wilayah rawan terjadinya konflik, adanya sinergi anatara masyarakat-TNI-Polri dalam melakukan pengawasan. Selain itu kondisi masyarakat yang memerlukan adanya peran-peran agama melalui ceramah agama melalui pengurus masjid. Namun penelitian ini menyadari bahwa selain peran tersebut, pemerintah juga perlu memperhatikan adanya penjualan miras yang kurang diawasi, dan buntunya dialog antar pihak dilakukan sehingga seringkali konflik terulang hanya karena dipicu oleh adanya salah paham yang sepele.
\end{abstract}

Kata Kunci: Strategi, Resolusi Konflik, Dialog

Abstract; Conflicts between communities are often repeated, there needs to be the lowest level of government participation in dealing with these problems. This study aims to describe the Strategy of the Government of Bone-Bone Village in handling conflicts between Batupoaro sub-district groups in Baubau City. This study uses a qualitative description research method, with the intention of explaining the problems that occur and the handling strategies from the bureaucratic side. This study explains that the kelurahan government strategy in dealing with citizen conflicts is carried out in three stages, namely: conflict prevention through mapping of areas prone to conflict, the synergy between the people-TNI-Polri in conducting surveillance. In addition, the condition of the community requires the existence of religious roles through religious lectures through mosque administrators. However, this study realizes that in addition to this role, the government also needs to pay attention to the sale of alcoholic beverages that are not monitored, and the lack of dialogue between parties is carried out so that conflicts often recur only because they are triggered by a trivial misunderstanding.

Keywords: Strategy, Resolution Conflict, Dialogue 


\section{Pendahuluan}

Konflik sudah menjadi bagian dari kehidupan manusia. Ketika orang memperebutkan sebuah area, mereka tidak hanya memperebutkan sebidang tanah saja, namun juga sumber daya alam seperti air dan hutan yang terkandung di dalamnya bahwa pada umunya orang berkompetisi untuk memperebutkan sumber daya alam karena empat alasan utama. Pertama, karena sumber daya alam yang memungkinkan perilaku seseorang mampu mempengaruhi perilaku orang lain. Sumber daya alam juga memiliki aspek yang menghasilkan hubungan-hubungan tertentu diantara para pelaku. Selain itu sumber daya alam bisa menjadi langka atau hilang sama sekali terkait dengan perubahan lingkungan, permintaan pasar dan distribusi yang tidak merata. Yang terakhir, sumber daya alam pada derajat tertentu juga menjadi sebagai simbol bagi orang atau kelompok tertentu.

Konflik merupakan kenyataan hidup, tidak terhindarkan dan sering bersifat kreatif. Konflik terjadi ketika tujuan masyarakat tidak sejalan, berbagai perbedaan pendapat dan konflik biasanya bisa diselesaikan tanpa kekerasaan, dan sering menghasilkan situasi yang lebih baik bagi sebagian besar atau semua pihak yang terlibat (Fisher, 2001). Sedangkan, Ralf Dahrendorf (2017), teori konflik adalah suatu perpektif yang memandang masyarakat sebagai sistem sosial yang terdiri atas kepentingankepentingan yang berbeda dimana ada suatu usaha untuk menaklukan kelompoklain guna memenuhi kepentingan lainya atau memenuhi kepentingan sebesar-besarnya.

Kontak atau hubungan merupakan landasan dari semua proses sosial. Persaingan atau kompetisi adalah suatu bentuk perjuangan sosial secara damai, yang terjadi apabila dua pihak berlomba atau merebutkan untuk mencapai suatu tujuan atau suatu barang yang sama. Perjuangan itu terjadi untuk mendapatkan suatu status, memperbaiki status dan untuk memperoleh kekuasaan. Soerjono Soekanto (2014) menyatakan bahwa konflik adalah pertentangan untuk usaha memenuhi tujuan dengan cara menentang pihak lawan. Jadi konflik merupakan bagian dari masyarakat yang selalu ada, sehingga apabila ada masyarakat maka konflik akan selalu muncul. Konflik juga bisa terjadi oleh kesalahan dalam pola komunikasi yang berlangsung (Suherman, 2016).

Berdasarkan pengamatan peneliti, terlihat adanya tawuran antara warga Kelurahan Bone-Bone, Tarafu dan Wameo memuncak saat salah seorang warga Kelurahan Tarafu yang meninggal dunia di bagian jalan Kelurahan Bone-Bone sekitar pukul 05.00 Wita, menurut informasi dari warga setempat bahwa korban tersebut meninggal karena menabrak tiang warung, tetapi informasi yang beredar di warga Kelurahan Tarafu dan Wameo disebabkan oleh pembunuhan berencana oleh warga Kelurahan Bone-Bone, hasil penyelidikan 
dari pihak kepolisian selama beberapa hari menyimpulkan bahwa korban murni meninggal karena kecelakaan lalu lintas dalam kondisi mabuk, mendengarkan informasi dari pihak kepolisian tersebut sebagian kalangan muda tidak menerimanya sehingga konflik kembali terjadi lagi yang memanenggarai masih masalah lama.

Pecahnya konflik kembali terjadi di perbatasan Kelurahan Bone-Bone dan Kelurhaan Tarafu, masyarakat sekitar tidak mengetahui apa penyebab yang dilakukan anak muda didaerah tersebut dan mereka dijadikan korban, baik rumah warga yang dilempari maupun timbulnya rasa was-was masyarakat. Hanya pihak kepolisian yang tampil digarda terdepan mengamankan situasi dan kondisi, dengan memblokir jalan umum kedua wilayah tersebut. Solusi pun dicari, Polisi, pihak Pemerintah Kecamatan maupun Kelurahan, tokoh masyarakat kedua wilayah dipertemukan dalam satu forum, dan disepakati untuk berdamai lagi. Namun, apakah perjanjian damai itu akan bertahan lama, tentu tidak ada jaminan. Inilah yang harus diselasaikan dalam mencari solusi pertikaian di daerah pertikaian antara pemuda Bone-bone dengan warga tetangga disekitarnya.

Selain itu, Kapolres Baubau, mengintruksikan seluruh polsek di wilayah hukum Polres Baubau khususnya polsek sekitar wilayah konflik tersebut untuk melakukan razia terharap warga yang minum minuman keras, termasuk jika ada oknum anggota polisi yang kedapatan meminum miras itu akan diberi sanksi dengan tindakan yang tegas."Saya sudah perintahkan 'zero' miras di wilayah tersebut. Mudahmudahan dengan apa yang kita lakukan itu ada efek jera, sehingga persoalan di masyarakat itu tidak berkembang luas," katanya.

(Sumber http://www.antarasultra.com, 2016).

Salah seorang tokoh masyarakat Bone-bone yang saya wawancarai awal bapak Kasim bahwa konflik ini hanya kelakuan remaja dan pemuda yang selalu mabuk dan membuat onar sehingga kejadian merembes pada persoalan balas dendam antar kelompok pemuda menjalar pada nilai-nilai kebencian dendam lama, sehingga hal konflik ini menjadi lebih besar pengaruhnya antara kedua mkelompok masyarakat Bone-bone dan tarafu, sehingga hal ini perlu penanganan lebih serius bagi pemerintah dan pihak kepolisian. Dengan mengamati hal itu, kondisi ini seperti pernyataan Theodore M Newwcomb, dkk (2008: 591) mengemukakan dalam kondisi-kondisi tertentu pada individu-individu terdapat penurunan ambang-ambang tingkahlaku kekerasan dalam bentuk-bentuk yang lebih ekstrem daripada yang dibenarkanoleh norma-norma yang biasanya mengatur kehidupan sehari-hari mereka

Permasalahan konflik antar masyarakat di tiga kelurahan (Bone-Bone, Tarafu, dan Wameo) harusnya dapat dituntaskan pada level tokoh masyarakat yang difasilitasi oleh pihak kepolisian dengan mengidentifikasi penyebab konflik yang selama ini dialami oleh 
warga setempat, oleh karena itu dibutuhkan sikap serius pemerintah kelurahan untuk melakukan pemetaan wilayah konflik, kelompok pemuda yang diduga melakukan tindakan teror terhadap warga, tetapi hal ini belum dilakukan.

Penyebab semuanya ini adalah minuman keras menjadi salah satu kendala dari pemerintah kelurahan dan kepolisian untuk menyelesaikan konflik antar warga, selama adanya kebiasaan minum alkohol maka akan lebih mudah melakukan provokasi dengan warga untuk berujung pada penyerangan warga yang lain, oleh karena itu tindakan tawuran antar warga bukan hanya sekedar menghentikan pertikaian itu dengan melakukan perundingan damai tetapi faktor-faktor lain seperti tingkat kemiskinan, mudah tersinggung, kurang penegakan hukum dan lain-lain yang memicu munculnya kembali tawuran lagi. Untuk itu diperlukan pendekatan yang konprehensip untuk menyelesaikan kejadian ini terlulang terus menerus, baik dari tokoh masyarakat pemuda dan pemeritah harus bersatu menyelesaikan akar masalahnya.

\section{Metode Penelitian}

Penelitian ini menggunakan metode penelitian kualitatif dengan maksud suatu penelitian yang mengungkapkan gejala-gejala secara holistik-kontekstual (menyeluruh dan sesuai dengan konteks),melalui pengumpulan data dari latar alami sebagi sumber dengan instrumen kunci peneliti itu sendiri (Suyitno, 2006: 5). Lokasi penelitian ini ditetapkan pada Kelurahan Bone-Bone Kecamatan Batupoaro Kota Baubau. Karena kelurahan ini merupakan sala-satu tempat terjadinya pertikaian atau konflik antar kelompok yang menyebabkan menjadi konflik diangai berbagai pihak pemerintah dan kepolisian Kota Baubau.

\section{Pembahasan}

\section{a. Strategi Pemerintah Kelurahan Bone-Bone Dalam Menangani Konflik antar Kelompok Masyarakat}

\section{Pencegahan Konflik}

Pencegahan konflik merupakan bagian dari persoalan yang harus di selsaikan oleh pemerintah. Mengetahui seluk beluk konflik antar warga ini, banyak caradan jalan untuk mencapai sebuah perdamaian yang ideal. Namun syarat utamanyaadalah ketika kedua belah pihak saling membuka diri dan membuka hati. Sulitnya membuka diri untuk menerima kelompok lain hadir dalam kehidupan kita danmembuka hati untuk saling memaafkan ini dikarenakan dalam berkehidupan kita tidak sendiri, melainkan adanya orang lain yang semuanya itu harus kita dengarkan akan.

Proses penyelesaian yang dilakukan oleh pemerintah kelurahan dalam mencegah adanya konflik kembali terulang lagi dilakukan dengan berbagai macam cara misalnya dengan melakukan rekonsiliasi, pemetaan wilayah yang 
rawan konflik, memberikan arahan dan sanksi sebagai bentuk penyelsaikan persoalan yang ada, sehingga tempat konflik difokuskan pada pengawasan ditempat yang sama dengan melibatkan pihak keamanan seperti anggota Polri dan TNI bersama-sama masyarakat menjadikan kondusivitas wilayah tersebut, pemetaan wilayah dilakukan agar tidak terjadi generalisasi atas permasalahan ini sehingga hanya tertuju pada oknum-oknum yang melakukan provokasi terhadap warga, disamping itu upaya ceramah agama melalui pengurus masjid masing-masing, hal ini dilatar belakangi oleh warga yang beragama muslim paling banyak dibanding dengan penganut agama lainnya sehingga cara inidianggap cocok mengadakan metode persuasif kepada semua elemen masyarakat.

Dalam upaya penciptaan rasa aman dan ketenangan di wilayah Kelurahan Bone-Bone, maka berbagai langkah telah dilaksanakan oleh Lurah. Langkah-langkah tersebut di atas merupakan wujud nyata tindakan dari pemerintah kelurahan untuk menghindarkan masyarakat dari gangguan keamanan. Sebagai bentuk riil dari upaya penciptaan keamanan maka pihak kelurahan bersama-sama dengan warga membangun pos-pos siskamling di setiap lingkungan yang ada di kelurahan. Pembangunan pos-pos ini merupakan swadaya warga Kelurahan Bone-Bone, yang dibantu dengan sumbangan sukarela dari masyarakat baik secara materi maupun tenaga.Untuk operasional pos siskamling ini maka pihak pemerintah kelurahan menyerahkan kepercayaan kepada warga untuk secara bergantian menjaga pos-pos tersebut.

Dalam hal ini mayoritas lingkungan memberdayakan para pemuda-pemuda yang berada di lingkungannya untuk melakukan kegiatan ronda setiap malam. Sebagai bentuk partisipasi masyarakat yang tidak terlibat langsung dalam penjagaan pos biasanya secara sukarela mereka akan memberi sumbangan materi untuk mendukung operasional siskamling tersebut tetapi bukan dalam hal melaksanakan pungutan uang jaga malam karena melakuakn ronda malam adalah kesadaran warga setempat untuk menjaga lingkungan masing-masing, ditambah situasi konflik yang sulit dideteksi artinya sewaktuwaktu bisa terjadi bentrok antar pemuda kelurahan.

Disamping program siskamling, pemerintah kelurahan juga menekankan kepada masyarakat untuk melaksanakan pemasangan lampu-lampu neon (TL) di depan ruko atau rumah tempat tinggal masing-masing. Himbauan ini dikeluarkan demi mendukung suasana yang terang yang diharapkan mampu meminimalisir tindakan kejahatan atau tindakan kriminal di tengah-tengah masyarakat. Sedangkan untuk mengantisipasi maraknya penggunaan miras pihak pemerintah kelurahan telah melakukan berbagai upaya dengan cara mengadakan sosialisasi tentang bahaya minuman keras. 
Dalam hal ketertiban, Lurah BoneBone bekerja sama dengan aparat kepolisian benar-benar konsisten dalam pelaksanaan peraturan-peraturan dan tata tertib yang berlaku. Terkendalinya ketentraman dan ketertiban masyarakat dapat meningkatkan kredibilitas dan kewibawaan aparatur pemerintah kelurahan. Lurah bersama petugas trantib sebagai pemelihara keamanan dan ketertiban sekaligus pengayom masyarakat harus mampu melaksanakan tugas dan kewajibannya secara profesional. Untuk mendukung pelaksanaan tugas dan fungsi tersebut, diperlukan dukungan sarana dan prasarana serta teknologi yang memadai. Disamping itu sikap mental dan perilaku aparat yang adil, profesional dan penuh pengabdian menjadi faktor bagi keberhasilan penegakan hukum, ketentraman dan ketertiban masyarakat.

Dalam upaya pembina dan menciptakan ketertiban, Lurah BoneBone mengupayakan baik yang tertulis maupun yang tidak tertulis. Pembangunan sosial kemasyarakatan, ketertraman ketertiban masyarakat dimaksudkan untuk mewujudkan masyarakat sadar aturan/norma, taat hukum, tertib dan menghayati hak serta kewajibannya sebagai anggota masyarakat, guna menumbuhkembangkan disiplin dan tanggung jawab sosial bagi setiap warga Kelurahan Bone-Bone sekaligus sebagai penduduk Kota Baubau. Disamping hal tersebut dalam mengupayakan ketertiban di wilayah Kelurahan Bone-Bone lebih menekankan kepada kesadaran dan moral masyarakat serta mengekspose norma-norma atau pranata yang sudah ada pada masyarakat tersebut. Sehingga kesadaran bermasyararakat mampu memahami persoalan kemanusiaan dan saling bergotong royong dalam setiap kegiatan kemasyarakat.

\section{Penghentian Konflik}

Pemerintah Kelurahan Bone-Bone akan memprioritaskan penyelesaian konflik antar kelompok yang ada yang kerap kali bertikai dan menganggu suasan keamanan dan ketertiban masyarakat (Kantibmas) di daerah itu. Aparat kepolisian sering berjaga-jaga di wilayah perbatasan Kelurahan Bonebone dan Tarafu, guna mengantisipasi agar bentrokan tidak terjadi kembali.. Bentrok yang terjadi lalu itu, antara warga Kelurahan Bone-Bone dan warga Kelurahan Tarafu ini saling serang di perbatasan kelurahan, menyebabkan sejumlah terluka akibat terkena lemparan batu dan anak panah.Tak hanya itu, beberapa rumah warga rusak terkena lemparan batu. Polisi yang tiba dilokasi kejadian langsung melepaskan tembakan peringatan ke udara.

Bentrokan mereda dua jam kemudian, setelah polisi membubarkan paksa kerumunan warga dengan tembakan gas air mata. Saat menangkap sejumlah pelaku, warga sempat menghalau petugas agar tidak membawa para pelaku ke kantor polisi. Belum 
diketahui penyebab terjadinya tawuran, namun diduga tawuran tersulut dendam lama dua kelompok pemuda dari masingmasing kelurahan. Konflik antar warga Kelurahan Bone-Bone dan Tarafu sudah berlangsung sejak lama, berbagai upaya mediasi yang dilakukan pihak kepolisian dan pemerintah setempat belum membuahkan hasil.

Untuk memberikan solusi terhadap konflik antarpribadi/kelompok (interpersonal conflict), Diperlukan strategi yang efektif sebagai berikut: Dari ketiga strategi di atas, strategi kalah-kalah (lose-lose strategy), strategi menang-kalah (win-lose strategy) dan strategi menangmenang (win-win strategy) ini, strategi kalah-kalah (lose-lose strategy) adalah strategi yang dipakai dalam perjanjian konflik antar warga dengan jenis strategi arbitrase.

Dalam permasalahan konflik antar warga ini, adanya pihak ketiga yang dirasa memberikan ikatan perjanjian yang kurang pas dan tidak menyentuh pada keinginan masing-masing pihak maka perjanjian ini kurang sesuai untuk permasalahan ini dan perjanjian yang ada belum dianggap sebagai sebuah perjanjian yang diinginkan.

Dari keseluruhan pembahasan data dan fakta yang ada maka bisa kita ketahui model perdamaian yang ideal dan tepat untuk menyelesaikan permasalahan konflik antar warga ini dengan menggunakan strategi menang-menang (win-win strategy) dengan cara konsultasi proses antarpihak (inter-part process consultation). Strategi menang-menang ini dianggap pas untuk menyelesaikan permasalahan konflik antar warga ini dikarenakan ketika masing-masing pihak merasakan kemenangan maka tidak ada pihak yang merasa bahwa pihaknya adalah lemah dan dalam posisi kalah. Mengkonsultasikan proses antar pihak ini merupakan cara terbaik untuk mengetahui keinginan masing-masing pihak.

Kejadian konflik pada bulan Oktober 2015 yang telah lewat merupakan pukulan keras terhadap warga Tarafu untuk merubah etikanya dalam menjalani kehidupan bersama masyarakat luas. Perubahan etika warga Tarafu dan Bone-bone ini merupakan dorongan dari individu warga tersebut dikarenakan keinginan untuk bisa hidup tenang dan damai merupakan keinginan dan kemenangan ketiga warga kelurahan yang bertikai. Dari model perjanjian strategi menang-menang (win-win strategy) ini diharapkan rasa bangga hati dan tidak merasa direndahkan akan menjadi sebuah solusi yang tepat untuk menghindari sebuah konflik laten susulan dikemudian hari. Sikap saling terbuka dan memaafkan seluruh kesalahan yang telah kedua belah pihak lakukan adalah langkah utama dalam menjalani kehidupan baru kearah yang lebih baik dan harmonis.

Warga di stiga kelurahan yang berkonflik di Kota Baubau, yakni Kelurahan Bonebone, Tarafu dan Bonebone menggelar ikrar sepakat berdamai pada acara buka puasa bersama Pemerintah Kota Baubau, Polres Baubau, 
Kodim 1413 Buton serta masyarakat lingkungan ketiga wilayah itu di perbatasan Bonebone-Tarafu.

Upaya yang dilakukan oleh pemerintah kelurahan untuk mencegah terulangnya kembali pertikaian antar warga berakhir dengan tidak sia-sia, pada hari Selasa tanggal 9 Februari 2016 telah berlangsung kegiatan "Ikrar / janji damai pemuda Kelurahan Bone-bone, BoneBone Dan Tarafu di kantor Camat Batupoara kota Baubau. Ikrar/Janji yang disepakati para pihak yang bertikai merupakan wujud nyata kesadaran para pemuda tentang pentingnya situasi yang kondusif diwilayah kota Baubau agar pembangunan diwilayah Baubau terhambat. Dalam pertemuan tersebut tokoh pemuda dari kelurahan yang bertikai membacakan ikrar / deklarasi damai yang isinya:

a. Kami bersedia melakukan perdamaian dan saling memaafkan,

b. Kami tidak akan memprovokasi atau terprovokasi terhadap hal-hal yang dapat menyebabkan terjadinya konflik atau pertikaian serta senantiasa menjaga keamanan dan ketertiban masyarakat.

c. Kami tidak akan melindungi dan menyembunyikan oknum yang diduga terindikasi sebagai pemicu konflik atau pertikaian.

d. Kami siap menerima sanksi hukum apabila dikemudian hari terbukti memulai dan melakukan tindakan yang dapat menimbulkan konflik dan pertikaian baik dalam kecamatan batupoaro maupun dengan pemuda kelurahan lain dalam wilayah kota Baubau,

e. Kami siap berkerja sama secara aktif dengan pihak penegak hukum agar segera menemukan dalang atau provokator yang menyebabkan terjadinya konflik dan pertikaian. (Sumber : Dokumen Pemeritah Kelurahan Bone-bone).

Kegiatan Janji/Ikrar dipimpin oleh Walikota Baubau ( Drs. H. AS Tamrin, MH) dan dihadiri oleh : Kapolres Baubau (AKBP Eko Wahyuniawan, S.Ik), ketua DPRD Baubau (Roslina Rahim),Sekda Kota Baubau (Drs. Muh. djudul, M.Si), Asisten 1 Kota Baubau (Ld Aswad),Kasat Pol PP Kota Baubau (Drs. Syamsul Bahri), Camat Batupoaro (Firman Adriansyah AP), Danramil 1413-01/Wolio (Mayor Inf Buhari), staf intel Kejaksaan Baubau (Nur Rahmat, SH), Lurah Tarafu (Wa Ode Nikmatia, S.Sos), Lurah Bone-Bone (Muhammad Firman SS), Lurah Bonebone (Drs. Ahmad Noer), Tokoh Pemuda ketiga kelurahan, serta kurang lebih 70 orang pemuda kelurahan Bone-Bone, Tarafu, dan Bone-bone. (Sumber informasi :Pemerintah Kelurahan Bonebone 2017).

\section{Upaya Pemulihan Pascakonflik}

Upaya yang dilakukan pemerintah bersepakat setelah dilakukan rekonsiliasi maka kejadian konflik di tiga kelurahan (Bone-bone, Tarafu, dan wameo), banyak menyisahkan kesan yang kurang baik dibenak masyarakat. Untuk itu diberikan alternatif-alternatif pemecahan untuk mengurangi kejadian serupa, selain 
rekonsiliasi banyak juga program yang diberikan untuk mencegah sala-satunya didirikan pos keamanan bersama diperbatasan wilayah tersebut.

Tabel 1. Strategi Pemerintah Kelurahan Bone-bone dalam Menangani Konflik Antar Pemuda

\begin{tabular}{|l|l|l|}
\hline No & Strategi & Keterangan \\
\hline 1. & Pencegahan Konflik & $\begin{array}{l}\text { Melakukan Pencerahan dengan tausiyah } \\
\text { keagamaan }\end{array}$ \\
\cline { 3 - 3 } & & $\begin{array}{l}\text { Melakukan sosialisasi hukum tentang akibat } \\
\text { yang ditimbulkan dalam konflik dan akan } \\
\text { terkena sanksi pidana yang keras }\end{array}$ \\
\cline { 3 - 3 } & & $\begin{array}{l}\text { Melakukan pendekatan dalam kegiatan seni } \\
\text { dan olahraga }\end{array}$ \\
\hline 2. & Penghentian Konflik & Pengawasan keamanan disetiap RT dan RW \\
\cline { 3 - 3 } & & $\begin{array}{l}\text { Sosialisai dan himbauan tentang keamanan } \\
\text { da ketertiban bersama }\end{array}$ \\
\cline { 3 - 4 } & $\begin{array}{l}\text { penyelesaian koflik dalam kesepakatan } \\
\text { bersama stakholder }\end{array}$ \\
\hline 3. & Pemulihan pasca konflik & $\begin{array}{l}\text { Melaksanakan rekonsiliasi dalam kerja } \\
\text { nyata dilapangan }\end{array}$ \\
\cline { 3 - 4 } & & Pendirian posko keamanan bersama \\
\cline { 3 - 4 } & $\begin{array}{l}\text { Melaksanakan gotong royong dalam kerja } \\
\text { bakti bersama dan nonton bareng }\end{array}$ \\
\hline
\end{tabular}

(Sumber : diolah dari hasil wawancara 2017)

\section{Kesimpulan}

Strategi Pencegahan konflik seperti upaya yang dilakukan oleh pemerintah kelurahan dalam mencegah adanya konflik kembali terulang lagi dengan melakukan pemetaan wilayah yang rawan konflik, Pengawasan dengan melibatkan pihak keamanan seperti anggota Polri dan TNI bersama-sama masyarakat, Melakukan penyuluhan seperti upaya ceramah agama melalui pengurus masjid dan sosialisasi hukum. Sedangkan upaya penghentian konflik seperti pemerintah Kelurahan Bone-Bone memprioritaskan penyelesaian konflik antarkelompok, adapun strategi yang dipakai dalam perjanjian konflik antar warga dengan jenis strategi arbitrase dan 
keuntungan secara adil kedua belah pihak yang sedang berkonflik. Jadi Upaya Pemulihan Pascakonflik seperti menjalin kerukunan antar warga karena warga Bone-bone, Tarafu, dan Bone-Bone adalah bersaudara.

Namun disisi lain, hasil penelitian ini menemukan bahwa kendala yang dihadapi dalam penangaan konflik warga baik persoalan kendala internal bagaiamana profesional aparat dalam menyelesaikan suatu persoalan masaalah, kurangnya ketersediaan anggaran kesinambungan penanganan suatu konflik. Sedangkan dalam kendala eksternal penegakan hukum dalam setiap persoalan tidak dilakukan secara serius serta kesadaran masyarakat khusunya pemuda belum maksimal dibarengi dengan dendam lama masih terus ada.

\section{Daftar Pustaka}

Arikunto, 2006. Prosedur Penelitian. Jakarta : PT. Rineka Cipta

Campbell, Tom. 2004. Tujuh Teori Sosial: Sketsa, Penilaian, Perbandingan. Terjemahan. Yogyakarta: Kanisius.

Craib, Ian. 2006. Teori-Teori Sosial Modern Dari Parsons Sampai Habermas. Cetakan Ke-tiga, Rajawali Pers, 1994.

Kartono, Kartini. 2009. Psikologi Sosial Perusahaan Industri, Rajawali, Jakarta

Masternbroek, WFG. 2006. Penanganan Konflik dan Pertumbuhan Organisasi (Diterjemahkan Oleh Pandam Guritno). Jakarta, Universitas Indonesia Press.

Nasikun 2003. Sistem Sosial Indonesia, PT. Raja Grafindo Persada: Jakarta.
Newwcomb, Theodore M dkk. 2008. Psikologi Sosial. Bandung: CV.Diponegoro.

Peraturan Pemerintah Republik Indonesia Nomor 72 tahun 2005 tentang Kelurahan

Pickering, Peg .2006. How to Manage Conflict (Kiat Menangani Konflik) alih bahasa: Masri Maris. Ensensi, Jakarta

Rauf, Maswadi. 2001. Konsensus dan Konflik Politik: Sebuah Penjajagan Teoritis. Jakarta: Direktorat Jenderal Pendidikan Tinggi Departemen Pendidikan Nasional.

Salusu. 2003. Pengambilan Keputusan Stratejik Untuk Organisasi Publik dan Organisasi Nonprofit. Jakarta : Grasindo

Siswoyo, 2003. "Konflik Tanah HGU (HGU) di Era Reformasi (studi kasus di desa Banyuringin Kecamatan Singorojo Kabupaten Kendal)", Tesis, Program Pasca Sarjana Magister Kenotariatan Universitas Diponegoro

Suherman, A. (2016). Konflik Dalam Komunikasi Politik Antara Legislatif dan Eksekutif Dalam Menyikapi Rencana Tata Ruang dan Wilayah di Kabupaten Buton Selatan. Kybernan: Jurnal Studi Kepemerintahan, 1(1), 10-15.

Soekanto, Soejono 2008. Sosiologi Suatu Pengantar. Jakarta: Raja Grafindo Persada

Tambunan, Raymond. 2001. Tawuran Antar Remaja. (Online). Tersedia: http://www.epsikologi.com/remaja/161001.ht



